\title{
Chemical alteration of the Pleistocene sediments under influence basaltic sills in the Guaymas Basin, Gulf of California
}

\author{
Evgenii Goncharov ${ }^{1, *}$, Victor Kurnosov ${ }^{1}$, Yurii Konovalov ${ }^{1}$, Alfred Geptner ${ }^{1}$, Konstantin \\ Galin $^{1}$, and Nikolaii Ignatyev ${ }^{1}$ \\ ${ }^{1}$ Geological Institute of Russian Academy of Sciences, Moscow, Russia
}

\begin{abstract}
In Guaymas Basin of the Gulf of California Holes DSDP 478 и 481A were drilled (Ocean Drilling Program). Studying of the cores from the holes showed the alteration of chemical composition of sediments in zones of contacts with basaltic sills. In the altered sediments strong decreased content in the Corg. Especially strong it occurs in sediment, that is located between sills in complex of thin sills. In these sediments also strong decreased contentin the $\mathrm{Li}, \mathrm{Cu}, \mathrm{As}, \mathrm{Mo}, \mathrm{Ag}, \mathrm{Cd}, \mathrm{Sb}, \mathrm{Ta}, \mathrm{W}, \mathrm{Tl}, \mathrm{Pb}$, Bi.For the first time in Upper Pleistocene sediments altered under conditions short-time hydrothermal systems that were formed by intruded sills into sediment cover was analysis wide spectrum of microelements, including rare earth elements.
\end{abstract}

\section{Introduction}

The Gulf of California is a model of early stage forming of the oceans during the rifting of continental margins $[1,2]$, when sediments accumulate in spreading rifts at high speed $(1200-2300 \mathrm{~m} /$ million years). The sediment cover thickness varies from $100 \mathrm{~m}$. to $3 \mathrm{~km}$. Melts intrude into young unlithified sediments with a high content of sea water. Penetration of sills into the sediments is accompanied by the formation of short-term hydrothermal systems in which alteration of sediments occurs during contacts with the sills. This phenomenon of Guaymas Basin was studied earlier [3,4]. We continued this research on the base of this study, significantly expanding the spectrum of the trace elements.

\section{Objects and methods}

The Guaymas Basin is located in the main fault zone of the Gulf of California, consisting of a system of spreading axes and transform faults (Fig. 1a). In the basin, Upper Pleistocene sediments are several hundred meters thick and consist of turbidites interbedded with hemipelagic sediments, and diatomaceous ooze [5].

\footnotetext{
* Corresponding author: evgeniigonch91@gmail.com
} 
In the Guaymas Basin there are the southern and northern troughs, which are spreading centers. Hole 481A was drilled to a depth of $384 \mathrm{~m}$ in the northern trough and Hole 478 is located between these troughs and was drilled to a depth of $464 \mathrm{~m}$ (Fig. 1b). Sills of different thickness were encountered in these holes. Holes 478 and $481 \mathrm{~A}$ were drilled in areas with low heat flow which is beyond the limits of the main long-lived hydrothermal system $[6,7,8]$. In this case, sediments were altered only under the influence of sills without the matter from the main long-lived hydrothermal systems. The content of $\mathrm{Co}, \mathrm{Cr}$, $\mathrm{Cu}, \mathrm{Ni}, \mathrm{V}, \mathrm{Zn}$ in the sediments was studied by the XFA (X-ray fluorescence analysisearlier) [4]. The contents of macro elements in sediments were determined by the XFA method at the Geological Institute (Russian Academy of Sciences) coupled with methods of analytical chemistry for the separate determination of $\mathrm{Fe} 2 \mathrm{O} 3, \mathrm{FeO}, \mathrm{CO} 2$, Corg, and $\mathrm{H} 2 \mathrm{O}-$. The contents of microelements (REE included) were determined by the ICP-MS (Inductively coupled plasma mass spectrometry) method with the decomposition of powdered fraction samples in an autoclave. The ICP-MS analysis was accomplished in the laboratory for Nuclear-Physical and Mass Spectral Methods of Analysis (Institute of Microelectronics, Technology, and High Purity Materials, Russian Academy of Sciences).
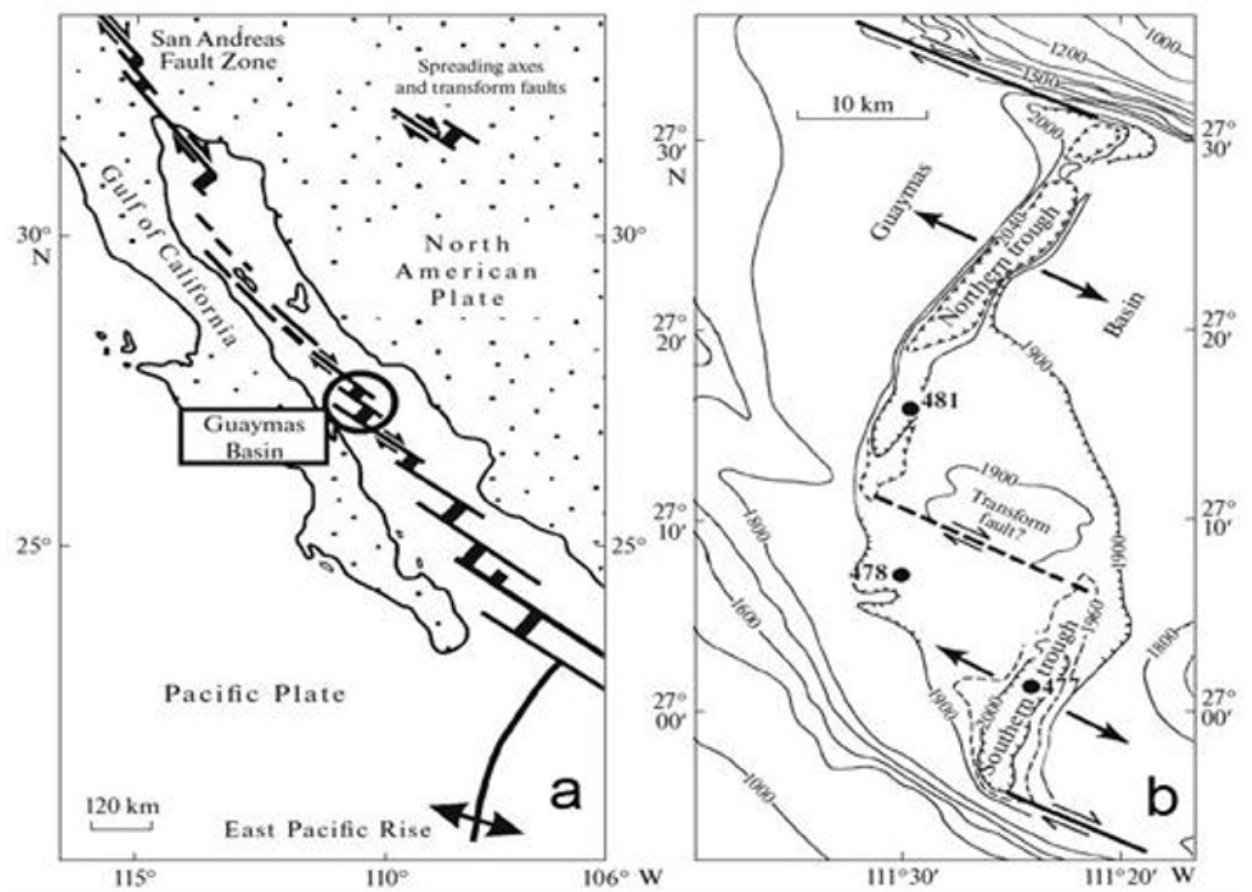

Fig. 1. Schematic structure of the Gulf of California (a) and location of DSDP holes in the Guayamas Basin (b). Modified after [9].

\section{Results}

The change in the chemical composition of the Upper Pleistocene sediments in the Guaymas Basin of the Gulf of California in the zones of contact with sills is as follows:

In the sediments, which are located inside the complex of thin sills and above it, above the complex of sills with a total thickness of at least 120 meters as well as above the roof and under the bottom of the sill with a thickness of about 3 meters the alteration for most macro elements is small or absent (Fig. 2a, b). This is due to the dissolution/deposition 
process in which such elements as diatom, opal CT, and quartz were primarily spotted. In result, the Si content in silicified sediments from thermally altered zones remains the same as well as in the original unaltered sediments. Also, there is no change in the content of macro elements in sediments as a result of the process of dissolution/deposition of clay minerals.

In altered sediments under the influence of the sills Corg. Content was decreased. This process was particularly intense in the sediments contained in the complex of thin sills (Fig. 2a). as the biggest decrease in the content of $\mathrm{Li}, \mathrm{Cu}, \mathrm{As}, \mathrm{Mo}, \mathrm{Ag}, \mathrm{Cd}, \mathrm{Sb}, \mathrm{Ta}, \mathrm{W}, \mathrm{Tl}, \mathrm{Pb}, \mathrm{Bi}$ occurred in them (Fig. 3). In the sediments from the zones of contact with other sills the content of a smaller set of trace elements was decreased.
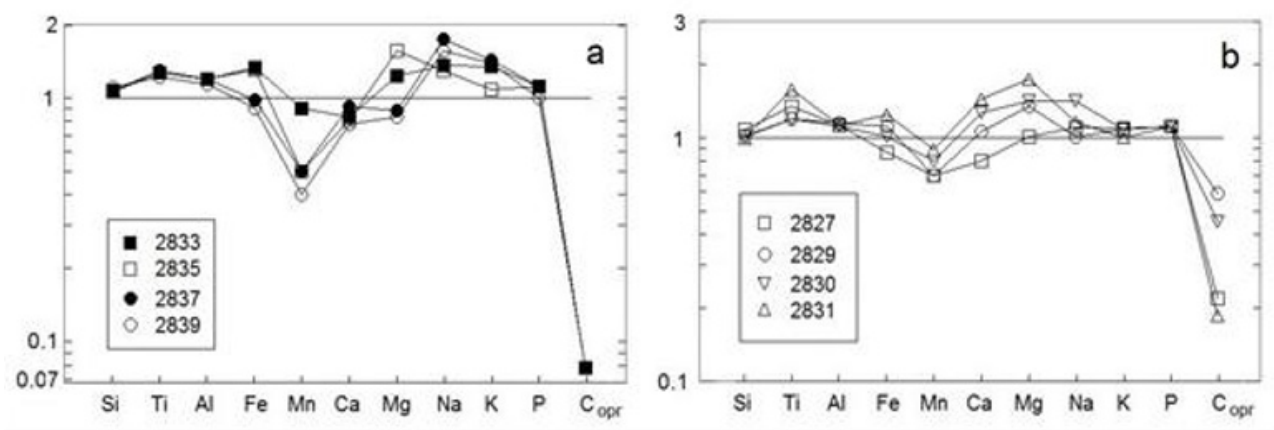

Fig. 2. Content of macro elements in the hydrothermally altered sediments from the thin sills complex (a) and sediments from contact with roof the thin sills complex (b) (normalized on the average content of macroelements in unaltered sediments), Hole 481A.

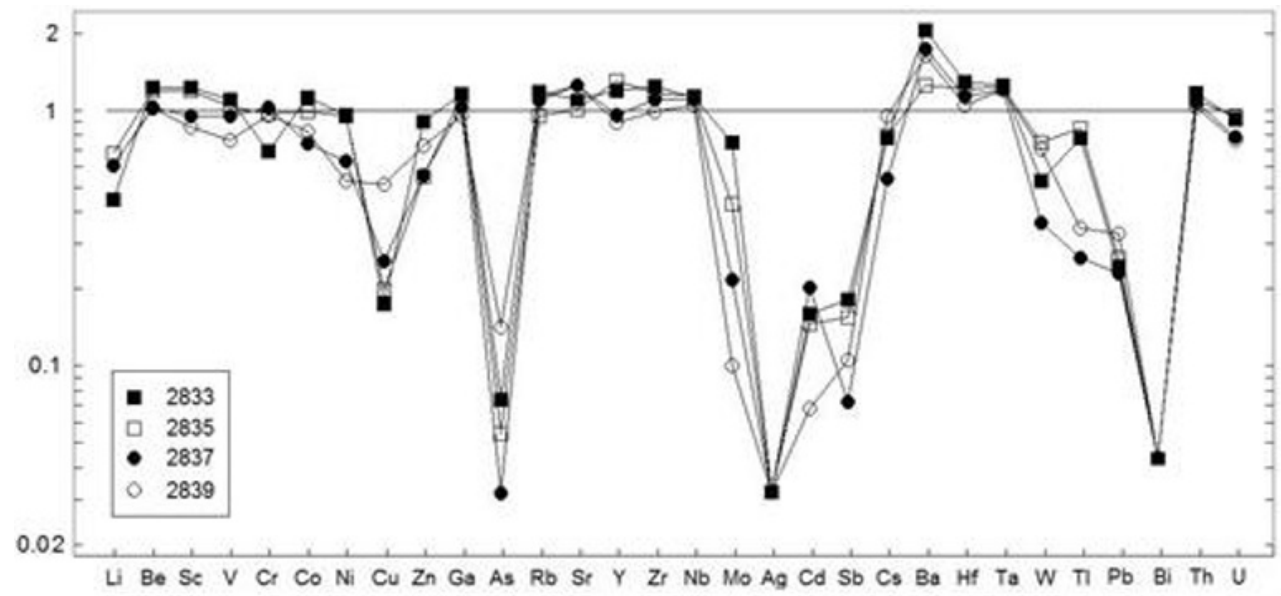

Fig. 3. Content of microelements in the hydrothermally altered sediments from the thin sills complex (normalized on the average content of microelements in unaltered sediments), Hole 481A.

In all sediments from the zones of contacts with sills the REE's content did not change or changed only slightly compared with their content in unchanged sediments, e.g. in hydrothermally altered sediments included in the complex of thin sills (Fig. 4). 


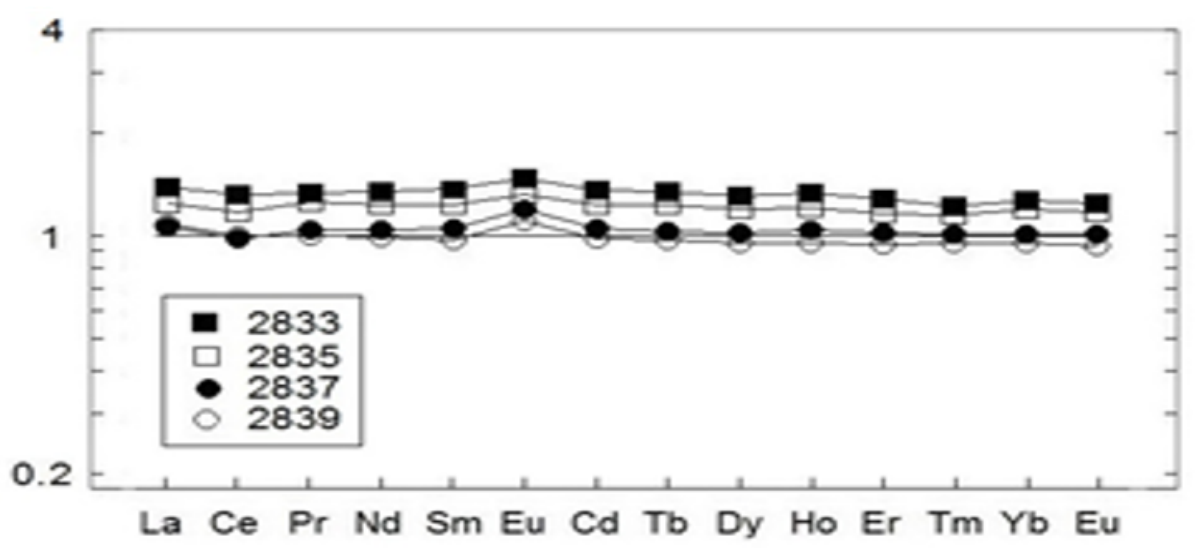

Fig. 4. Content of REE's in the hydrothermally altered sediments from the complex of sills (normalized based on the average content of REE's in unaltered sediments), Hole 481 A.

\section{Conclusions}

The results show a change in the chemical composition of sediments from the zones with sills contacts in the Guaymas Basin of the Gulf of California which is characterized by a high speed accumulation of thick units of sediments with high seawater content and the penetration of hot basalt sills in them accompanied by the formation of short-time hydrothermal systems. The results expand our knowledge about the processes which took place in ancient objects of a similar genesis and develops the idea of changing of chemical composition of sediments under the influence of sills. Additionally, the Guayamas Basin (Gulf of California) showed alteration of chemical composition of sediments at sills' magmatism as an example of the hydrothermal process typical of the early stages of ocean opening during continental margin rifting.

We used rock samples taken from the IODP Core Repository (College Station, Texas, Texas A\&M University, United States).

This work was accomplished under the State Program no. № 0135-2018-0038.

\section{References}

1. R.L. Larson, Bathymetry, magnetic anomalies, and plate tectonic history of the mouth of the Gulf of California. Bull. Geol. Soc. Am., 83, 3345-3360 (1972)

2. D.G. Moore, Plate-edge deformation and crustal growth, Gulf of California structural province. Geol. Soc. Am. Bull., 84, 1883-1906 (1973)

3. M. Kastner, Evidence for two distinct hydrothermal systems in the Guaymas Basin. Init. Repts. DSDP, 64, 2, 1143-1158 (1982)

4. J. Niemitz, Geochemistry of sediments, Leg 64, Gulf of California. Init. Repts. DSDP, 64, 2, 695-716 (1982)

5. J.R. Curray, D.G. Moore, et al., Init. Repts. DSDP. 64, 1, 507 (1982)

6. L.A. Lawver \& D.L. Williams, Heat flow in the central Gulf of California. J. Geophys., 84, 3465-3478 (1979) 
7. D.L. Williams, K. Becker, L.A. Lawver, R.P. Von Herzen, Heat flow at the spreading centers of the Guaymas Basin, Gulf of California. J. Geophys. Res., 84, 6757-6796 (1979)

8. J.M. Gieskes, H. Elderfield, J.R. Lawrence, J. Johnson, B. Meyers, A. Campbell, Geochemistry of interstitial waters and sediments, Leg 64, Gulf of California. Init. Repts. DSDP, 64, 2, 675-694 (1982)

9. P. Lonsdale, J.L. Bischoff, V.M. Burns, et al., A high-temperature hydrothermal deposit on the seabed at a Gulf of California spreading center. Earth and Planet. Sci. Lett., 49. 8-20 (1980) 